Journal of Teacher Education for Sustainability, vol. 12, no. 1, pp. 5-26, 2010

\title{
SELF-EVALUATION AS A TOOL IN DEVELOPING ENVIRONMENTAL RESPONSIBILITY
}

\author{
Paul Pace \\ University of Malta, Malta
}

\begin{abstract}
The purpose of the paper is to share the findings of an action research project aimed at exploring the impact of transformative pedagogies on pre-service teachers following an environmental education programme (EEP), offered by the University of Malta. Assessment and evaluation practices of environmental education (EE) and education for sustainable education (ESD) programmes tend to cater just for knowledge content and skills, usually failing to target the development of attitudes and values that promote sustainable lifestyles. The EEP was specifically designed to target the development of pro-environmental values by actively involving students in their learning mainly and providing opportunities for reflection and self-evaluation. The paper analyses qualitative research data obtained from evaluation questionnaires about every study unit in the programme; reflective questionnaires drawing upon the students' reflective journals; a focus group interview and in depth one-to-one interviews with individual students. The paper provides students' evaluations about the course design and effectiveness that should provide insights for course developers and evaluators seeking to develop EE/ ESD programmes that address individual needs through learner centred pedagogies.
\end{abstract}

Key words: education for sustainable development, environmental education, transformative pedagogies, self-evaluation, journal keeping, reflective writing

\section{Introduction}

Half-way into the UN Decade of Education for Sustainable Development educational institutions need to reflect on the mistakes and achievements of the past in order to avoid falling in the same pitfalls and ensure progress. For example, literature abounds with arguments justifying the shift towards education for sustainable development because environmental education failed to deliver what it promised. Rather than engaging in endless semantic issues about the meaning of the terms, what needs to be asked is why the implementation of environmental education failed (Leal Filho \& Pace, 2006). 
The important role that teacher education and universities have in preparing a cohort of individuals that have an environmental ethic, which is at the basis of a sustainable lifestyle, has been a recurrent theme in all major events related to environmental education (UNESCO, 1980; UNESCO-UNEP, 1988; Scoullos, 1998; Centre for Environment Education, 2007). The development of this ethic is dependent on transdisciplinarity, wide conceptualisations and a pedagogy that is primarily learner centred. Universities tend to be exactly the opposite: being more concerned with narrow monodisciplinary structures that promote the transmission of subject content. The development of an environmental ethic depends on whether "... knowledge is interrelated to personal behaviour and social values, and if the learner experiences ethical demands in decision making" (Schleicher, 1996, p. 32). The implication is that effective environmental education at universities is dependent on a change in praxis; and a change is not always a welcomed alternative.

This appraisal of universities in relation to their commitment towards sustainable development is further elaborated by Moore (2005a) who identifies the following four barriers that university based environmental education programmes face:

- Monodisciplinary organisational structures that determine funding, result in territorial conflicts and limit student mobility from one area to another.

- Competition between and within students, faculties, departments and universities.

- Misdirected criteria for evaluating staff and student abilities and achievements.

- Too many priorities, unclear decision-making and hierarchical power structures.

Moore (2005a) also proposes corresponding pathways to change: for example, research and teaching that is transdisciplinary; collaborative and transformative learning; participatory evaluation; a vision of sustainability that is owned by all the administrative strata of university.

Whether we refer to it as environmental education or education for sustainable development, its objectives (UNESCO, 1980; UNESCO, 2005) are multifaceted and complex. Achieving them necessitates the employment of diverse and integrated subject matter, diverse learning settings and a varied pedagogy that promotes participatory learning and higher-order thinking skills (Tal, 2005). Educational institutions, particularly higher education institutions, need to create, what Moore (2005b) calls space for pedagogical transformation that supports transformative and transdisciplinary learning. She goes on to highlight that this is not just physical space, but also time for learners to engage in reflection, dialogue and action. As opposed to banking pedagogies that view learners as passive depositories (Freire, 1970), these transformative pedagogies transform learners (and therefore classes and learning communities) into inquisitive, reflective, experienced and critical thinking individuals - the basic unit of a sustainable society.

Transformative pedagogies require an assessment programme that goes beyond traditional formats and addresses the various educational needs of the learner at the cognitive, psychomotor and affective levels (Tal, 2005). These assessment techniques (such as self-assessment, peer assessment, portfolios, reflective journals) support and promote learning and are gradually making their appearance in higher education courses. These new models of assessment focus on assessment for learning where the focus and 
first priority is to promote students' learning (Black, Harrison, Marshall, \& Wiliam, 2003). Assessment for learning, however, involves the learning of new skills and roles by both lecturers and students in order to develop what Buhagiar (2007) calls communities of shared practice. Rather than nurturing pecking order of the traditional classroom setting, these collaborative communities are dependent on the structures that promote dialogue in which teachers and students feel free and safe to share and critique each others' thinking.

As stated by Black et al. (2003), "an assessment activity can only help learning if it provides information to be used as feedback by teachers and by their students in assessing themselves and each other to modify the teaching and learning activities in which they are engaged" (p. 2). In practice at the tertiary level this relationship between learning and assessment is "not adequately translated into working guidelines" (Tal, 2005, p. 595). The absorption of such assessments within courses at higher education is still very slow mainly because such assessment practices are still looked upon as being a waste of precious time.

This paper documents, primarily from the learners' perspective, the educational outcomes of environmental education programme (EEP) at the University of Malta. In its design, care was taken to relate assessment procedures with the learning experiences to create a symbiotic association between them in which one supports the other. Although a mix of traditional assessment methods and innovative ones was used throughout the programme, this paper specifically focuses on the course evaluation from the pre-service teachers' viewpoint and their self-evaluation. Moreover, it also proposes the lessons learned from this experience that might provide important insights for the educators who wish to embark on a similar programme.

\section{The programme}

Set up in 1978, the Faculty of Education (University of Malta) is the only teacher education institution in the country. Although it has taken on a variety of roles linked to a wider conception of education and training, its main focus remains pre-service teacher education. Indeed, the largest proportion of students follow either the B.Ed.(Hons.) programme (a four-year undergraduate course preparing pre-service teachers either for primary education or for secondary education) or the Post Graduate Certificate of Education (PGCE) (a one-year course in secondary education for graduate students).

The EEP was designed by a team of three environmental educators from the Centre for Environmental Education \& Research (CEER) of which the author was a member. The aim was to provide prospective primary school teachers with the opportunity to specialise in environmental education as a part of their initial teacher education programme. Enrollment in the EEP was on a voluntary basis following an informative meeting for all $1^{\text {st }}$ year primary track students about the available specialisation areas that they could opt for in the subsequent years. The PowerPoint presentation used for the meeting presented the EEP as a personal journey and, after highlighting the cross-curricular nature of environmental education, it outlined the content of the study units. A total of 22 pre-service teachers $(31 \%)-21$ females and 1 male - registered for the course from a total of 72 students following the primary education track. 
The EEP was always presented as a learner's "personal journey of awareness, understanding, concern and commitment to action" and conscious efforts were made to present the course content as an integrated whole rather than a set of standalone units. Spread over three years, the programme was structured as shown in Table 1. As it becomes evident from the objectives of the course (Box I), the main concern of the course developers was developing the learners' (the pre-service teachers) competencies needed to become independent environmental educators. The course contained study units that fitted within the education about/through/for the environment paradigm. Besides providing the necessary content knowledge, the programme design ensured the provision of firsthand experiences and opportunities for reflection on personal environmental attitudes and values. In this way, a balance between these three components was maintained, rather than falling into the trap of placing a heavier emphasis on the about component as is the praxis in traditional courses (Pace, 1997a).

Consequently, the course co-ordinator (and author) issued guidelines for lecturers involved in the programme asking them to adopt participative methodologies ensuring that the students were actively involved in their learning. During face-to-face meetings with the lecturers, the course co-ordinator discussed the possible assessment procedures to be adopted to ensure the monitoring and evaluation of the students' development of their cognitive, psychomotor and affective abilities through a variety of tasks that had different attainment foci (Table 1).

Box 1. The EEP course objectives

By the end of the programme, students should ...

- understand the concept of the environment and the principle of sustainability

- explore the role of humans in the environment

- become familiar with the main environmental issues of the Maltese islands

- become familiar with the global environment / development issues

- use the principles of sustainability to critically analyse their lifestyle

- examine and clarify their attitudes and values regarding environmental issues

- become aware of the impact of environmental education on the educational system

- develop skills in the organisation of environmental education initiatives

- critically analyse environmental education programmes and initiatives

- develop action-oriented skills required to promote a sustainable society 


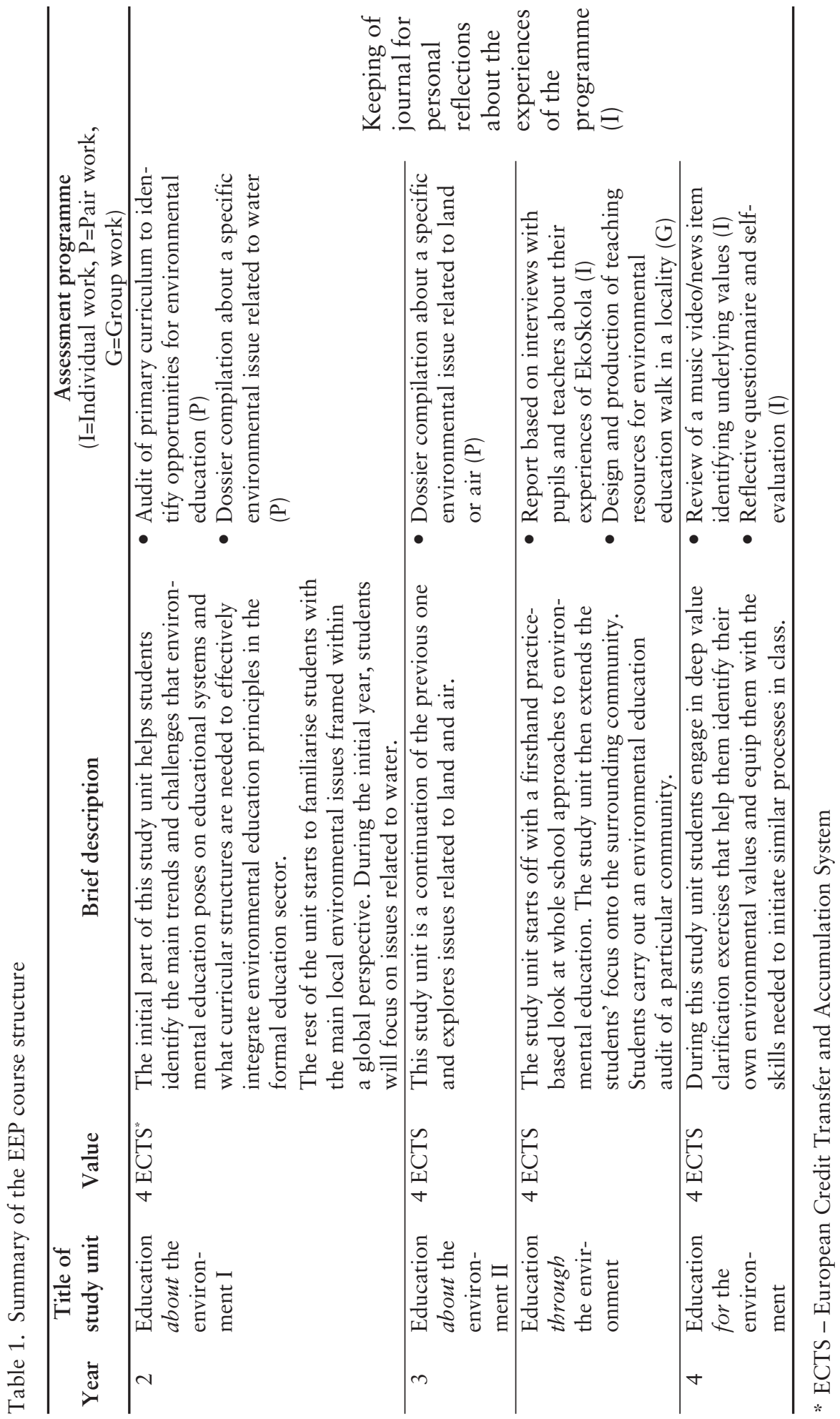




\section{The research methodology}

In certain educational courses, learners are presented with facts to be memorized and their success is judged by how many of these facts they manage to reproduce in examinations and tests. EEP's aim to develop independent critical learners did not fit with this genre of courses. EEP needed a structure that would provide learners with the time to assimilate what was presented: time to explore and analyse information from different perspectives; relate knowledge to personal and past experience; value its relevance and internalize it.

Reflective writing is one of the tools that help individuals go through this effective learning process preparing them for reflective practice (Pollard, 2005). Teachers' knowledge emerges from experience and practice, personal practical knowledge (Connelly \& Clandinin, 1988). Teachers' reflective writings are identified as an essential component of this knowledge and journals are one of the tools that can be used by teachers to understand and communicate what they know in a variety of ways (Cole \& Knowles, 2000). The students of the EEP were asked to keep a reflective journal throughout the programme in which they could both evaluate the individual study units and reflect on the impact the course was having on their personal development.

Nevertheless, reflective writing does not come naturally and students need help to understand the purpose of the process, as well as how to go about it (Moon, 2004). For this reason, a session was dedicated, at the very start of the programme, to prepare students for reflective writing. During this session, students were introduced to the aims of the reflective journal and how it fits with the general objectives of the programme. Students were also shown examples of typical journal entries and helped to discern the difference between descriptive and reflective writing. Although free writing, as opposed to presenting specific topics for reflection, was adopted, some sample questions and suggestions for reflection were provided to assist in the initial phases. It was made very clear that these were given as guidelines and that students were free to adopt any questions/topic they wanted. Due to their personal nature, the journals were never collected; however, students could discuss their entries, as well as clear out difficulties about keeping the journal with the course co-ordinator throughout the course during tutorial sessions.

In this research, the author wanted to explore and give voice to the pre-service teachers' beliefs and points of view about their practice. Qualitative research data consisting mainly of the personal, and hence very subjective, reflections of students provided in these journals was used. However, to respect the confidentiality of the journal entries, the author made use of data gathered from the following multiple sources:

1. Four evaluation questionnaires were given after every study unit in the programme asking students to comment on the quality, presentation techniques, follow-up and the theory/practice balance of the sessions. An average of 9 students submitted each of these questionnaires.

2. A reflective questionnaire whose open-ended questions asked students to make use of their journal entries to comment on their experiences before and during the course, their plans for the future and a self-evaluation of their performance was distributed. The questionnaire was given a week before the half-day seminar organised as the concluding activity of the EEP. All 22 students filled in this questionnaire. 
3. An audio recording of a focus group interview (with 7 students) during the EEP concluding seminar that explored various aspects of the reflective questionnaire in detail was made.

4. Audio recordings of one-to-one interviews were made towards the end of the final academic year with 5 individual students, who, besides following the course, decided to do their dissertation project on environmental education.

Since the data emerged from the pre-service teachers' personal knowledge, the information required was obtained from questionnaires and different forms of interviews so as to validate the data and ensure that it was trustworthy. This triangulation (Hammersley $\&$ Atkinson, 1990) of data ensured a more holistic, more entwined and more interrelated representation of the data.

The questionnaires provided a general overview of the pre-service teachers' writings and the interviews provided a more in depth view of the pre-service teachers' experiences and "the meaning they made of that experience" (Seidman, 1991, p. 3). Both focus group interviews and one-to-one interviews were used to ensure that a discussion was raised among the participants and, at the same time, get a more in depth view of individual student's thinking and feelings. The relationship developed between the students and the author was one of trust and students felt free to say anything they liked. The students were informed about the study being conducted and assured that all data would be confidential and would not be used to expose or harm them (Fontana \& Frey, 1994).

One of the major difficulties with reflective journal writing is deciding whether writing is reflective or not. As this was not important for the main aims of the study, even writing by pre-service teachers, which was purely descriptive and contained no critical analysis, was considered important and included in the analysis. The data was analysed by a reading and re-reading of the reflective journals of the students during which the author searched for patterns and connections and developed categories and themes (Seidman, 1991). These categories and themes were used to build the conceptual scheme of this paper.

\section{The results}

\section{(a) Before the programme}

Before commencing the programme, the vast majority of the students (20 out of 21) perceived environmental education as another subject primarily concerned with teaching about environmental facts.

... my idea was that environmental education was similar to environmental studies but I didn't realise there was an important difference in the course name which I did not give too much attention to when I heard about it for the first time. (Josette)

There were some (3) who even thought that the faculty was preparing them for a new subject that would be introduced in the primary school curriculum.

1 Unless otherwise stated all student quotes are taken from responses to the Reflective Questionnaire. This choice was made because all students responded to this questionnaire. To maintain anonymity, all names are fictitious. 
Since the primary sector is the only sector that does not have a subject specifically dedicated to the environment, I thought that the Education Division had plans to introduce it and that it had asked the Faculty of Education to start preparing teachers for it. (Lillian)

As it was offered by the Faculty of Education, students expected that the environmental knowledge provided by the EEP would not just provide facts, but also possible actions that could be taken to address the issues studied. Consequently, they thought that throughout the course they would be provided with skills and resources that they could use in their teaching and (in one case) to influence the whole school.

I thought that it is very similar to Environmental Science, but that it would include skills and handouts that I could use in my teaching practice ... and eventually in class. (Tony)

I expected that we would be given something like we had at post secondary level ... but we would be trained to move towards making schools environmentally friendly. (Rose)

Only one student introduced the personal dimension in her perception of environmental education.

I thought that environmental education, apart from giving you more knowledge about important aspects of life as a human, also makes you more responsible. (Kylie)

Keeping in mind the students' perception about environmental education, not surprisingly many of them (14 students) cited their previous experiences of similar subjects as the main reason for choosing this specialisation. They said that these subjects (Biology, Geography and Environmental Studies at secondary level and Biology, Environmental Science and Systems of Knowledge at post-secondary level) provided them with the required background they could build on.

Having come from a background of sciences in the ordinary level, I further pursued this by opting for Environmental Science at intermediate level. Studying this subject was something which I really enjoyed. Thus, when environmental education was proposed as an area of specialisation, I was thrilled and immediately sought out to further explore it. (Jane)

From the responses given by this cohort of 14 students, it is evident that while 9 students perceived their educational background as an opportunity to do better academically, the other 5 interpreted this advantage as an adequate foundation to learn more about environmental issues and hence be in a better position to teach children about them.

... because amongst the options we were given, it was the one which I had some background about and knew I could do better. (Joanne)

I wanted to learn more about the subject in order to be able to teach it. (Greta)

Three other students attributed their personal interest in environmental issues as the main reason for them to choose the specialisation. 
Being environmentally friendly has always been a priority in my life's agenda. I thought that choosing EE as my area of specialisation will help me grow in this aspect and give me an opportunity to pass it over to my students. (Lillian)

Good marketing strategies tend to give good results. The same seems to have occurred with the EEP. Seven students attributed the reason for their selection to the way the course was presented during the information meeting about the available specialisation options. The course came across as something interesting, well-planned and challenging.

The programme's overview struck me with its differentiated content. Unlike the other options presented, it sounded different and interesting. (Sarah)

I chose EE during the initial meeting where we were given a brief description on what each specialisation consisted of. I was immediately interested. This is due to the fact that it was presented as a forward looking programme, as an area where much more can be done and we can help make a difference. (Debbie)

When asked about what they expected to achieve through the EEP, all of the students (22) made it quite clear that they expected the course to prove useful for their future career as teachers. In other words, their main expectation was that going through the course would make them better teachers at dealing with environmental issues. The majority (16 students) felt that something needed to be done to ensure that environmental education given in schools is based on professional decisions rather than sporadic initiatives that fail to develop environmental responsibility in students. The students expected the EEP to provide them with this professional preparation.

Unfortunately, so much talk is done but action does not always follow so quickly. I think that that was something I was looking forward to learn: to be able to do something with the children, to help them understand the need to take care of their environment and try to help them become more caring about their environment. (Marilyn)

Others ( 5 students) expected the EEP to consolidate and build upon their personal environmental ethic. They felt that without a personal disposition towards environmental education a teacher cannot be effective in class and help children become environmentally responsible.

I expect ... to learn how to achieve a more sustainable way of living and thus to reflect upon my own behaviour vis-a-vis the environment ... to change my own actions and reflect on sustainable practices in the course of preparing to teach children. (Maria)

Rebecca extended this concept further and expected the EEP to be instrumental in making her a resource person in environmental education for the school she will be teaching in.

The ability to be able to organise environmental education activities for the whole school, once I'm assigned to one. (Rebecca)

This section of the reflective questionnaire clearly showed that these students, although having notions of environmental education that might conflict with the models described 
in the literature, have aspirations and expectations that are in line with the general targets of environmental education (UNESCO, 1980) and education for sustainable development (UNESCO, 2005).

\section{(b) During the programme}

One of the questions of the Reflective Questionnaire asked students to judge how much they learned from the EEP. They were asked to score their level of learning on a 6-point Likert scale ranging from Learned a Lot (6) to Learned Nothing (1) and to provide a reason for their choice. The scores obtained were mainly distributed around scores 6 and 5 ( 6 and 12 respectively), showing that the majority of the students felt that they had learned from the programme. Several reasons were given to substantiate this claim, but the most common response (17 out of 22) was that through the EEP's content/ practice mix, they learned a lot about local environmental issues and the situation of environmental education in Malta.

I learned about different subjects, such as the earth and different effects that are caused by humans. Then the theory learnt was put into practice by onsite visits and the EkoSkola visits. (Rose)

Other students (9) remarked that they developed a holistic view of the environment and consequently of environmental education that widened their perspectives on a conceptual level:

I learnt that the environment is a system of interrelationships. Just as we individuals need each other to live ... our environment operates in the same way in a system of interrelated parts that work together. (Rebecca)

I think that one of the most important things that I learnt was to open up my mind to new ideas and points of view. Before the course, my view of the environment was still a bit restricted. ... these study units have developed my way of thinking and made me more active and practical. While before I used to look around and see nothing worthwhile, now I am able to see endless opportunities for learning and things I can use to educate the children. ... Something else which I feel that I have learnt during the course was to look at issues from different points of view-social, political and economicand to try to analyse all the information and data available to form my opinions. (Marilyn)

Others commented that this widened view helped them conceive environmental education as a cross-curricular theme and influenced their professional practice.

I have learnt how I can integrate environmental education through all the main topics in the syllabus. In fact, I came to realise that environmental education can be a great help to children in order to understand some concepts. I also got to know how environmental education can make teaching so practical. (Emily)

The issue of innovating classroom practice through environmental education was specifically highlighted by other students (6) who felt that what they learned had empowered them and will in turn empower their students. 
I learned to cut down on classroom preaching and move on to actively involving my students ... environmental efforts will only succeed if environmental education is targeted at the community's grassroots level, from primary school onwards. ... They can learn strategies to extend their personal appreciation to a responsibility at work and in the political spectrum. (Maria)

A major contributing factor that seems to have left a marked impression on the preservice teachers was the infusion of environmental education principles in the way the EEP lectures were taught.

I can honestly say that (unlike other study units) throughout the EEP, lecturers practiced what they preached... They not only TOLD us how to do it ... (but) they showed us how by the way they tanght and related with us. (Lillian)

On the other hand, two students scored 3 on the 6-point Likert scale showing that they did not see themselves as having learned much from the EEP. They cite two major reasons for their assessment: (1) the theory/practice balance of the EEP was not kept, and (2) practical activities in schools showed the implementation problems environmental education faces in certain schools.

... lectures were given at two extremes: either too theoretical or with no basic theories at all. I did not comprehend everything on the theoretical aspect since the terms used were too difficult. I did not find the part which was non-theoretical useful as it was completely unstructured. (Joanne)

The visit to the EkoSkola school involved a lot of work that proved futile. This shows the difficulty of schools to include environmental education. (Rita)

Considering the students' evident preoccupation with experiencing the firsthand environmental education implementation in schools, when asked which sections of the EEP they found most relevant to their professional and personal needs, not surprisingly the majority of students (16) opted for the sections having a strong practical dimension: (1) the EkoSkola programme experience: providing students with an example of a whole school approach to environmental education and (2) the evaluation of environmental education potential of community resources.

These sections were most relevant to my professional needs because they had us indulge in activities and assignments which were concrete and which we could make good use of with the children in class. Personally I enjoy practical activities because I can see what we talked about coming to life, and when one sees it happen right in front of his eyes, one tends to believe more in the power of change and starts believing that there is a good possibility of materialising what we talked about. (Josette)

Some students (7) said that it was not easy to comment on the sections separately and remarked positively on the complementary nature of the sections.

I feel that the four sections cannot be reflected upon independently. Each had some kind of impact on me to some extent... They built on one another 
and each contributed in its own way to extending my awareness of environmental education. (Connie)

Although in some way or another almost all students commented on the impact the EEP had on their value framework, five students explicitly identified the section dedicated to the analysis of personal attitudes and values as being the most relevant.

This was the most relevant section because EE has to do with changing your lifestyle and with being a model for students and others. (Denise)

In a way all sections were relevant, but the section about values was very useful as it helped me relate environmental issues with me and my choices. I think that all people should be exposed to a similar study unit. (Claire)

The students were also asked to judge how much the EEP helped them change their perception of environmental education. They were asked to score their response on a 6-point Likert scale ranging from Changed a Lot (6) to Changed Nothing (1) and to provide a reason for their choice. The scores obtained were mainly distributed around scores 6,5 and 4 (5, 9 and 6 respectively), showing that the majority of the students felt that the EEP changed - to some degree - their perception of environmental education. In the reasons given for this choice there is a marked departure from the group's initial definition of environmental education (related to content knowledge about environmental topics).

The two most common reasons cited were: (1) the widening of their perception of the environment and consequently of environmental education (11 students) and (2) the consciousness of their impact on and role in the environment (6 students).

I have come to view environmental education as a much larger discipline than I had first envisioned; one which encircles not just natural aspects but also social, economic, cultural and political aspects. So to tackle it in an effective way it should not be tackled as a standalone subject, but incorporated in the everyday life of the school, as well as the classroom. (Maria)

I am much more aware of how my actions, no matter how small, can have an impact on the environment. This has made me think about my responsibility to do something tangible with my lifestyle ... although it is rather difficult. (Greta)

Other students (3) commented that although they had been convinced of the importance of environmental education before starting this programme, the EEP intensified this notion.

...made me more aware about the need for EE in classrooms. Children are not being given enough of it and therefore are being deprived from important aspects of their life. (Kylie)

Students were also asked to identify deficiencies in the learning programme of the EEP what they needed to and/or expected to learn that was not addressed in the prog-ramme. Three students clearly pointed out that their expectations were fully met by the EEP.

What one learns is never enough, however, I can confidently say that I learned more than I expected to learn at the beginning of the EEP. In fact, I am very grateful to have chosen EE as my area of specialisation. (Lillian) 
The most common response (14 students) was focused on the need for the EEP to give more emphasis on specific ideas for lesson plans and the provision of resources that they could use directly in class. The students felt that at times they needed more guidance on how to apply what they were learning to the level of the children they would be teaching.
The programme could do with more direct references to the classroom context, referring to the way we should deliver the content in terms of practical activities which are suitable for primary school children. I would like to have enough simple information about environmental issues that could be presented to children. I don't think I am able to simplify the material that we were given. (Angela)

The majority of these comments referred particularly to the content oriented study units. Although for some students (4) the material covered during these units was a repetition of their post-secondary level Environmental Science lessons, the rest found these units difficult to understand. As evidenced in the responses given in the study units evaluation questionnaires, these units were good for personal knowledge, but left the students bewildered as to what was relevant to schoolchildren. Moreover, it appears that too much information was presented at one go and there were times when the information imparted was too technical. Students commented that the redeeming factor was that these units were coupled with fieldwork sessions that managed to relate theoretical knowledge to reality. On the other hand, a small group of students (3) felt that, in their journey to become independent learners, there comes a time when they will be expected to take the helm and make their own choices about subject matter and pedagogical options. They felt that the EEP made them realise this commitment.
At first, I thought that I needed some guidelines and objectives along which I could organise lesson plans for the class when I'm a teacher myself. I would have appreciated more tips on how to use the information and adapt it for the children, but now I realise that it can be done by me. (Josette)

The other responses did not specifically mention any particular ingredient that was absent from the course. Their comments were mostly directed towards the emphasis made on certain aspects of the programme. Four students preferred more exposure to firsthand experiences in the field reiterating what the students had remarked in the study units evaluation questionnaires.

What I strongly suggest is improving the on-site visits - like visiting a valley to see the human impact on the environment. Going to different and opposing sites to give concrete examples how humans have improved or marred the environment. (Connie)

I feel that although we had quite a number of lectures and hands-on activities with children, I still feel that this was not enough. I thought that we were going to have a longer period on-task training since the (EkoSkola) programme in schools is ongoing. Once I got the grip of the procedures of EkoSkola, it was time to continue with our usual lectures. (Martha)

One student referred to the methodology adopted by the lecturers and suggested: 
Something I wish could have been done during the course was to have more group work and discussions. I do realise that there were occasions when we were asked to contribute our opinions about certain topics and subjects, but I think that it is not something that we were used to doing at university. Maybe, by organising workshops and more group work sessions, we would have been able to discuss issues together as a whole group. I think that this would have been beneficial in itself since it would have allowed us to share our ideas and opinions with each other, thus allowing us to learn from our own course mates. (Marilyn)

This issue had surfaced in the study units evaluation questionnaires and was followed up in the focus group interview. Several EEP lecturers reported that their continuous prompting of students to participate in discussions and to voice opinions was met by a general apprehension. Attempts to start a class discussion usually ended up in a 'private' conversation between the lecturer and a handful of 'bolder' students, with the rest of the class being passive bystanders. The students confirmed that this attitude was due to them "feeling too self-conscious and afraid to make mistakes ... all the more reason why lecturers should avoid relenting from adopting this methodology" (Amy - focus group interview).

\section{(c) Following the programme}

Students were also asked to judge the extent to which the EEP influenced their teaching on a 6-point Likert scale ranging from Influenced a Lot (6) to Not Influenced at all (1) and to provide a reason for their choice. The scores obtained were mainly distributed around scores 6 and 5 ( 7 and 12 respectively), showing that the majority of the students felt that the EEP influenced their teaching.

The vast majority of the students (18) reported that since they had started the EEP they started planning their lessons differently by looking for opportunities of infusing environmental education within the curriculum and/or in the interactive methodology adopted in class. The EEP helped them in building up their confidence and they now feel capable of engaging students in environmental issues.

Although I have always been environmentally concerned in my teaching, the EEP led me to plan lessons and practice values promoted by EE, such as leaving the room for children to share the decision-making process with the teacher and amongst others. (Lillian)

The EEP has influenced a lot my approach to teaching because it made me realise that basically 'good environmental education is ultimately a good education'. The EEP made me further aware that education does not simply involve teaching children to read and write.... I should strive to stimulate and develop the pupils' problem solving skills and provide them with what they need to be able to make responsible choices for a more sustainable life. (Debbie)

While all the other students seemed to be very positive and motivated about the influence the EEP had on their teaching, Rita was still overwhelmed by the implementation problems that environmental education has to face. Scoring 3 on the 6-point Likert scale, she commented: 
I would have ticked 6, but due to syllabus restraints I cannot say that I would manage to include environmental education as much as I desire. (Rita)

When asked whether they intend to pursue environmental education in their teaching career, all the students said that they would. Six students commented that they will do this by putting into practice what was learned in the EEP and hence improve their teaching.

I plan to draw up a set of cross-curricular lesson plans for my students based on the ideas and themes I learnt from the EEP. (Rose)

The plans of another eight students went beyond the classroom. They are planning to become resource persons in their school for environmental education. Some even wished to become peripatetic teachers whose task would be that of infusing environmental education in schools.

I intend to take the initiative in the school I am assigned in, to organise activities and discussions about environmental issues. I will try to encourage other teachers to join in and enter our school in the EkoSkola project. I believe that I can be useful in helping the school adopt a whole school approach. (Rebecca)

I would like to be a peripatetic teacher to be able to promote environmental education in our primary schools. In the future, I also dream of co-ordinating some kind of programme for students and teachers. (Connie)

Three other students wish to go beyond schooling and see environmental education as an instrument of change in the community.

I want to play a part in causing environmental awareness and moving tomorrow's adults towards more sustainable living practices. I hope to do this through education, activist work, lobbying and other ways in order to make a constructive change. (Maria)

Almost half of the group (10) clearly highlighted their intention of furthering their specialisation by reading for a master's degree in environmental education, particularly after settling in their teaching.

I wish to pursue EE further, but I am still not aware of the opportunities that exist in this area. I would love to carry out a masters in the subject, but first I prefer to get some classroom experience. (Sarah)

\section{(d) Self-evaluation}

This section of the Reflective Questionnaire was aimed to help students to self-evaluate and consequently grade their efforts in the EEP. The purpose of using self-assessment with the pre-service teachers was to enhance their learning and enable them to make value judgements about their own learning. Self-assessment was seen as a tool allowing students to become more responsible and more involved in their own learning (Weeden, Winter, \& Broadfoot, 2002).

However, students find it very difficult to assess themselves, especially if they do not have a clear picture of the targets their learning is meant to achieve and hence need more guidance to go about it (Black \& Wiliam, 1998). 
While claiming that students are capable of self-assessment, Weeden et al. (2002) stress that they need to be familiar with the assessment criteria prior to the assessment and the learning objectives. They would also require examples of good practice and an opportunity to discuss their work. Consequently, EEP students were provided with (1) the Course Objectives and a 10-point Likert scale on which they could mark the degree to which they had achieved each objective, (2) the Grade Descriptors, (3) space to jot down the mark/grade that they feel they deserved and (4) space to provide evidence to substantiate their choice. The students could later discuss/defend their mark/grade choice during a small group (7) discussion chaired by a course tutor. (The group chaired by the author was the group participating in the focus group interview).

Table 2 and Figure 1 show the distribution of the grades before and after the focus group interview. Quite understandably there was some degree of inflated grades proposed by the students. The agreed grades were the result of negotiations between students and lecturers and between students themselves during the focus group interviews.

Table 2. Distribution of grade/mark

\begin{tabular}{lcccccccccccc}
\hline \multirow{2}{*}{$\begin{array}{c}\text { Number } \\
\text { of students }\end{array}$} & \multicolumn{10}{c}{ Grade/Mark } \\
\cline { 2 - 12 } & A+/95 & A/94 & A/90 & A/89 & A/85 & A/83 & B+/79 & B+/76 & B+/75 & B/74 & B/70 \\
\hline $\begin{array}{l}\text { Before focus } \\
\text { group interview }\end{array}$ & 4 & 1 & 9 & 1 & 1 & 1 & 2 & 1 & 0 & 1 & 1 \\
\hline $\begin{array}{l}\text { After focus } \\
\text { group interview }\end{array}$ & 0 & 1 & 10 & 1 & 3 & 1 & 2 & 1 & 1 & 1 & 1 \\
\hline
\end{tabular}

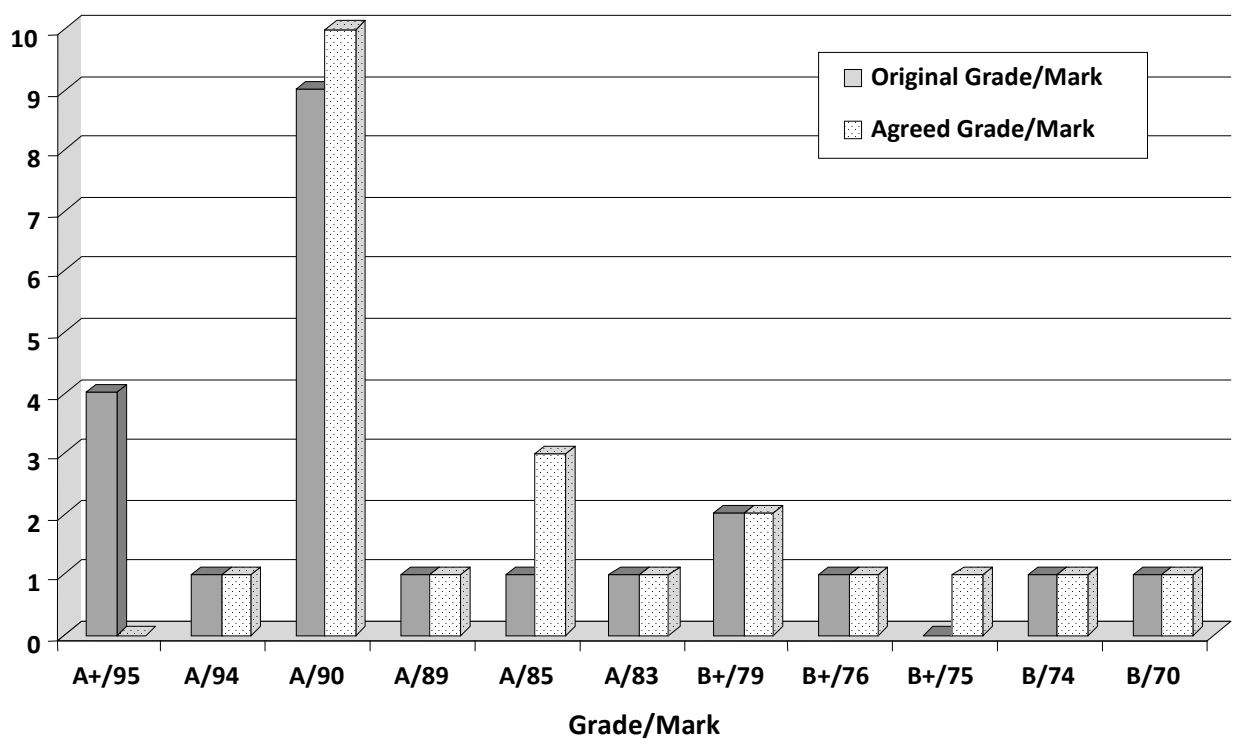

Figure 1. Distribution of grades/marks

This process resulted in the alteration of six grades, all of which were scaled down. The comments from the students whose grade was reduced included: 
I was sure that the grade would be reduced ... but I did not want to reduce it myself and lose the chance of getting a better grade because of my low expectations. (Amy - one-to-one interview)

I really enjoyed myself during this programme, and I also felt that I learned a lot as a teacher and an individual. My grade was based on these feelings. But when I heard what the other students were saying, that is, the mark that they had suggested, I decided to lower it and bring it more in line with those of the rest. It's only fair! (Angela - one-to-one interview)

Although students' participation in the process was satisfactory, some had second thoughts about this new form of evaluation and assessment as shown by this extract from the focus group interview:

Tania: $\quad$ I prefer the traditional way of assessment. Finding a suitable grade proved to be a hard task.

Amy: $\quad$ I agree with you, I found this method really stressful.

Researcher: In what way?

Amy: $\quad$ I felt awkward ... we are more accustomed to undervalue our work rather than to praise it.

Researcher: But don't you think that this method is fairer?

Sarah: $\quad$ Personally I saw it as a challenge. I was given the opportunity to evaluate my efforts. (Addressing her mates) Have you forgotten how frustrated we get when, after spending days working on an assignment, the lecturer assigns a mark that is not a just one?

Researcher: After all, isn't this what you'll be doing when you correct students' scripts?

Tania: But when it's YOUR work it's different.

Researcher: How?

Tania: $\quad$ Because of what [Amy] said ... it feels funny and odd to say I deserve an A or an A+'... because of what others might say or think about your pretensions.

Various students mentioned a combination of reasons to justify their mark/grade, but the awkward feeling was clearly reflected in the justifications given by the students. The majority of the students (14) tried to adopt an 'objective' approach by calculating the average mark/grade from the results of earlier assignments.

Having been asked to substantiate the grade and mark I chose, I was very apt in doing so, as I found all the grades being awarded throughout this journey and drew up an average to safeguard my decision. (Jane)

This particular student also supplemented her argument by reproducing feedback remarks that course tutors had written on her assignment. Other 'objective' criteria used focused on their commitment towards the course requirements (10 students) and the degree of achievement of the course objectives (6 students).

I have regularly attended lectures, participated in discussions and showed enthusiasm for the subject. I have obtained good grades in all assignments 
given. This reflects an understanding of the issues involved, reasonable reading and research in the subject and good team work whenever it was a group assignment. I took further interest in the subject and made additional research by opting to do my thesis in environmental education. (Denise)

Looking back to where I have started this journey, I feel I have achieved or nearly achieved most of the objectives. I know that there is still a lot to be achieved, but, so far, I feel quite satisfied with my achievements. (Connie)

Having established these 'objective' and hence 'undeniable' reasons for their proposed grade/mark, students felt safer to focus their attention on other 'non-measurable' criteria, such as (1) commitment towards integrating environmental education in their teaching, (2) having a personal interest in environmental education and (3) having changed as a person.

The most important thing, in my opinion, is that I don't intend to stop here but I'm looking forward to having a class of my own so I can try to include environmental education and also educational outings. (Amy)

I willingly chose to study this subject, and I had more motivation to learn a subject in which I was particularly interested. (Rita)

Throughout the EEP I worked upon myself, as well as upon my own values and attitudes.... I believe that this programme was really beneficial for me because ... it helped me go through a personal growth. (Debbie)

\section{Discussion}

The research results showed that the vast majority of the students enrolling for the EEP had no clear idea of what environmental education (or education for sustainable development for that matter) meant. Nevertheless, as the EEP progressed, their reflections evidence a gradual unfolding and development of attitudes and values that are in line with the declared objectives of both environmental education and education for sustainable development. Their common denominator was a genuine interest in environmental issues (most commonly the natural environment) and a wish to safeguard it. Throughout the programme, the students developed this very basic notion to a much wider conceptualisation aligned with sustainable development principles.

This further stresses the futility of the anxieties some writers seem to have about the importance of finding the right term for the process. It is very evident that these semantic concerns do not feature high in the list of priorities of people working directly in the field. For example, Karameris, Ragkou and Papanikolaou (2006) found that for teachers these subtle differences do not seem to be an issue since they use them interchangeably. What is important is that, whatever it is called, its principles are those identified over the years by conferences, which turn to education to re-establish sustainable modes of life. These protracted academic debates tend to generate confusion in people who are not directly involved in research and could prove problematic and exclusive (Leal Filho \& Pace, 2006). In countries where environmental education is still struggling to get recognition, because governments have other seemingly more urgent socio-economic priorities, changing goal posts by introducing new terms might throw years of negotiation and hard-won success down the drain (Leal Filho, 1996; Smyth, 2002). In fact, even a 
cursory analysis shows that sustainable development has only been given lip service and a general lack of political will has been identified as the principal cause for its slow implementation (United Nations, 2002).

A lack of political support may result in a patchwork approach to environmental education implementation that does not adequately cater for the needs of citizens. A wellplanned strategy, on the other hand, targeting specific objectives and specific audiences ensures that sustainable development principles are integrated in the everyday experiences and concerns of citizens. In fact, the majority of EEP students attributed their choice to join the EEP to their previous encounter with environment related subjects and experiences.

Exposing students to participatory methodologies is not enough. The students' responses showed that there is an acclimatisation period during which students gradually adapt to this new style of learning that challenges the deeply rooted notion of student passivity that years of teacher-centred education engendered. Adapting from an educational process where students received everything they need for an education in which they are shown how to do it and then expected to do it takes time. Consequently, although this attitude changed as the programme progressed, it was still quite strong in some students although some had finally realised the benefits of becoming autonomous learners.

Environmental education course designers are always faced with the dilemma about how much handholding is required. Since the students have different learning needs, some may need more help than others, and, therefore, in this case, what's good for the goose is certainly not good for the gander. To cater for the various learning needs, course tutors need to function on a more personal level. The use of peer tutoring and collaborative group work promotes increased interactions between the students themselves and with their tutors and could provide a solution. On the other hand, technological advances have also presented the possibility of developing Virtual Learning Environments that offer personalised support.

The students' responses also highlighted the importance they attribute to hands-on practical sessions and field experiences as part of their education. Once again, their responses indicate that these experiences still need to be supported to ensure that maximum benefit is obtained. The results showed that, for some, experiencing the harsh realities of schools was discouraging and demotivating. Supervised practical/on-site experiences coupled with follow-up reflection sessions in groups might provide the support required to help the students to function in the unsheltered environment of schools. Dealing with conflict within the safe environment of a student-group session could help the students build up the self-confidence required to help them face the pressures to accept the status quo that they will encounter when they are qualified teachers.

If certain clichés are true, then the saying that values are caught not taught was proved right by the students' responses. The students commented that the methodology used by the lecturers had a positive effect on their personal teaching styles. In fact, although student expectations initially revolved around their need to deepen their environmental knowledge, as the programme unravelled, their concern shifted towards discovering ways of improving their teaching and their teaching environment. If environmental education courses adopt the accepted principles of environmental education (or education for sustainable development) in their praxis, rather than just teach about them, school practice will eventually change for the better (Pace, 1997b).

Van Petegem, Blieck, Imbrecht and Van Hout (2005) point out that for any innovation to take root, teachers need opportunities during which they can familiarise 
themselves with the proposed new teaching technologies; time to develop a personal (and peer) vision about the innovation and the possibility of airing their aspirations, needs, emotions and fears. This will progressively lead the whole educational institution to incorporate the innovation within its institutional ethos. For this to apply to environmental education, there needs to be an initial commitment towards its principles, otherwise concern about sustainable development will only be superficial.

Helping learners to develop attitudes and values that promote sustainable development is not just an issue of what content matter to include in a course. It is more related to a methodological choice - a choice that allows learners to examine whether espoused values (considered appropriate) tally with their actual values that determine their lifestyles and consequently their teaching style. The EEP aimed to achieve this by adopting a two-pronged strategy: promoting systematic reflection and self-assessment.

The students' comments showed that the EEP's provisions for systematic reflection paid off. These provisions, besides helping students to develop their practice, also helped them in their professional development. Moreover, their comments evidence the development of a readiness to challenge conventional perspectives on teacher knowledge (Cole \& Knowles, 2000).

Adopting a sustainable lifestyle inherently implies making decisions based on specific criteria and objectives; and devising strategies to achieve them. Once again, student comments showed how the self assessment procedures adopted by EEP helped to empower students with their own assessment skills, allowing them to understand the learning objectives and leading them to success (Weeden et al., 2002).

\section{Conclusion}

Putting the learner back at the centre of educational discourse might sound rhetorical, but the students' experiences reported in this study show that it's worth the trouble. There are, however, three major lessons to be learnt from this study:

- The true change factor that influenced student behaviour was the methodology adopted during the programme rather than what content matter was provided. Experiencing methodologies that acknowledged different learning needs and provided opportunities for active engagement in learning enabled students to develop skills, attitudes and values necessary for the promotion of sustainable development principles.

- Responding to the different learning needs of students was only possible through a novel way of designing, implementing and evaluating an educational programme. Educational institutions (particularly universities) need to adapt their administrative structures to promote and be more open to new and alternative approaches.

- The EEP experience evidences that change - both institutional and personal occurs gradually and in small steps, provided an institution and an individual learner is given space to grow.

Achieving these targets is inversely proportional to our (both as educators and educational institutions) level of attachment to deeply set educational traditions. Until there is this paradigm shift in emphasis, the targets set for the UN Decade of Education for Sustainable Development will never be truly achieved. 


\section{References:}

Black, P., Harrison, C., Marshall, B., \& Wiliam, D. (2003). Assessment for learning: Putting it into practice. Maidenhead: Open University Press.

Black, P., \& Wiliam, D. (1998). Inside the black box. London: King's College.

Buhagiar, M. A. (2007). Classroom assessment within the alternative assessment paradigm: Revisiting the territory. The Curriculum Journal, 18(1), 39-56.

Centre for Environment Education. (2007). Moving forward from Abmedabad ... environmental education in the $21^{\text {st }}$ century. Retrieved May 22, 2009, from http://www.tbilisiplus30.org/Final Recommendations.pdf

Cole, A. L., \& Knowles J. G. (2000). Researching teaching. Boston: Allyn and Bacon.

Connelly, F. M., \& Clandinin, D. J. (1988). Teachers as curriculum planners: Narratives of experience. New York: Teachers College Press.

Fontana, A., \& Frey, J. (1994). Interviewing: The art of science. In N. Denzin \& Y. Lincoln (Eds.), Handbook of qualitative Research (pp. 361-376). Thousand Oaks, CA: Sage.

Freire, P. (1970). Pedagogy of the oppressed. New York: Continuum Publishing Company.

Hammersley, M., \& Atkinson, P. (1990). Ethnography: Principles in practice. London and New York: Routledge Publications.

Karameris, A., Ragkou, P., \& Papanikolaou, A. (2006). Study of primary and secondary school environmental educators' understandings of sustainable development, education for sustainable development and its relation with environmental education. In E. I. Manolas (Ed.), Proceedings of the 2006 Naxos International Conference on Sustainable Management and Development of Mountainous and Island Areas. Vol. 1 (pp. 181-187). Department of Forestry and Management of the Environment \& Natural Resources, Democritus University of Thrace, Greece.

Leal Filho, W. (1996). Furthering environmental education. In W. Leal Filho, Z. Murphy, \& K. O'Loan (Eds.), A sourcebook for environmental education: A practical review based on the Belgrade Charter (pp. 182-195). London: The Parthenon Publishing Group.

Leal Filho, W., \& Pace, P. (2006). The UN Decade of Education for Sustainable Development: Meeting the challenges or another missed opportunity? In E. I. Manolas (Ed.), Proceedings of the 2006 Naxos International Conference on Sustainable Management and Development of Mountainous and Island Areas. Vol. 1 (pp. $105-$ 113). Dept. of Forestry and Management of the Environment \& Natural Resources, Democritus University of Thrace, Greece.

Moon, J. (2004). A handbook of reflective and experiential learning: Theory and practice. London: Routledge Falmer Press.

Moore, J. (2005a). Barriers and pathways to creating sustainability education programs: Policy rhetoric and reality. Environmental Education and Research, 11(5), 537555.

Moore, J. (2005b). Seven recommendations for creating sustainability education at the university level: A guide for change agents. International Journal of Sustainability in Higher Education, 6(4), 326-339.

Pace, P. (1997a). Environmental education in Malta: Trends and challenges. Environmental Education Research, 3(1), 69-82. 
Pace, P. (1997b). Environmental education and teacher education in Malta. Unpublished doctoral thesis, University of Bradford, Bradford.

Pollard, A. (2005). Reflective teaching. London: Continuum Publishing Company.

Schleicher, K. (1996). Environmental ethics. In W. Leal Filho, F. MacDermot, \& J. Padgham (Eds.), Implementing sustainable development at university level (pp. 28-37.). Bradford: European Research \& Training Centre on Environmental Education, University of Bradford.

Scoullos, M. J. (1998). (Ed.). Environment and society: Education and public awareness for sustainability. Proceedings of the Thessaloniki International Conference, 8-12 December 1997. UNESCO \& Government of Greece.

Seidman, I. E. (1991). Interviewing as qualitative research: A guide for researchers in education and the social sciences. New York: Teacher's College Press.

Smyth, J. C. (2002). Are educators ready for the next Earth Summit? Millennium Papers Series, 6. London: Stakeholder Forum for Our Common Future.

Tal, T. (2005). Implementing multiple assessment modes in an interdisciplinary environmental education course. Environmental Education and Research, 11(5), 575-601.

UNESCO. (1980). Environmental education in the light of the Tbilisi conference. France: UNESCO.

UNESCO. (2005). Report by the Director-General on the United Nations Decade of Education for Sustainable Development: International implementation scheme and UNESCO's contribution to the implementation of the Decade. Paris: UNESCO.

UNESCO-UNEP. (1988). International strategy for action in the field of environmental education and training for the 1990s. Paris, Nairobi: UNESCO-UNEP.

United Nations. (2002). Report of the World Summit on Sustainable Development. Johannesburg, South Africa, 26 August - 4 September 2002. New York: United Nations.

Van Petegem, P., Blieck, A., Imbrecht, I., \& Van Hout, T. (2005). Implementing environmental education in pre-service teacher training. Environmental Education and Research, 11(2), 161-171.

Weeden, P., Winter, J., \& Broadfoot, P. (2002). Assessment: What's in it for schools? London: Routledge Falmer Press.

\section{Acknowledgements:}

I would like to thank Dr Deborah Chetcuti and Dr Michael Buhagiar, from the University of Malta, for their insightful comments during the review of the final draft of this paper.

\section{Correspondence:}

Dr Paul Pace, Faculty of Education, Centre for Environmental Education and Research, University of Malta, Msida MSD 2080, Malta. Tel: + 3562340 2331; Fax: + 3562131 7938. Email: paul.j.pace@um.edu.mt 